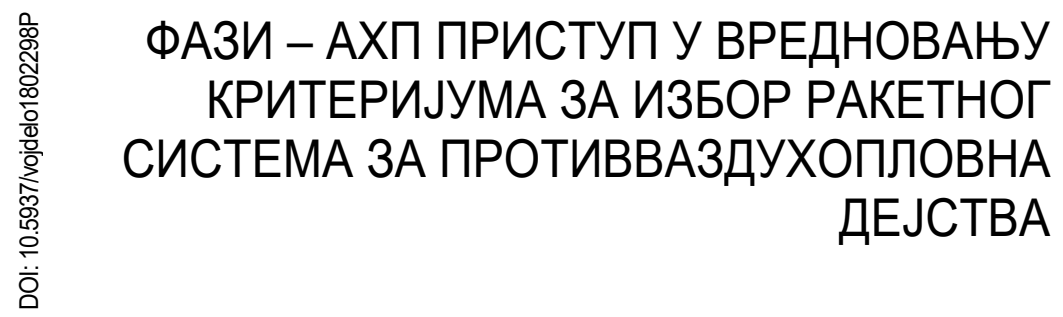

\author{
Иван Б. Петровић \\ Универзитет одбране у Београду, Војна академија \\ Миодраг Л. Гордић \\ Факултет за међународну политику и безбедност, Београд \\ Милан С. Канкараш \\ Универзитет одбране у Београду, Војна академија
}

\begin{abstract}
V саопштењу је приказана могућност приоритетизације критеријума и атрибута критеријума за избор ракетног система за противваздухопловна дејства. Анализом садржаја доступне литературе издвојени су критеријуми на основу којих је могуће вредновати алтернативе понуђених ракетних система средњег домета. Међусобни утицај критеријума и атрибута извршен је тестирањем групе експерата помоћу деветостепене скале судова. Обрада добијених података и приоритетитизација критеријума и атрибута извршена је применом фази - АХП методе и односи се на опремање државе савременим ракетним системом за противваздухопловна дејства. Конзистентност резултата испитана је степеном конзистентности. На основу добијених резултата предложен је модел који омогућује избор оптималног ракетног система за противваздухопловна дејства средњег домета.
\end{abstract}

Кључне речи: фрази - АХП, вишекритеријумска анализа, ракетни систем за противваздухопловна дејства, модел

\title{
Увод
}

сторијско - компаративном анализом конвенционалних оружаних сукоба ко-

ји су се одиграли на крају XX и почетком XXI века може се уочити да Ратно ваздухопловство и противваздухопловна одбрана играју кључну улогу у остваривању стратегијских циљева. Док, са једне стране авијација, начелно моћније стране у сукобу, својим дејствима покушава да уништи центар гравитације и значајно утиче на исход сукоба, дотле противваздухопловна одбрана, обично слабије стране у сукобу, својим дејствима и осталим борбеним и неборбеним активностима покушава да онемогући авијацију у остваривању својих циљева. У противваздухопловној одбрани посебно место и улогу у савременим оружаним сукобима имају и ракетне јединице за противваздухопловна дејства, чија способност вођења оружане борбе са 
непријатељевом авијацијом зависи највише од могућности система оружја којим је опремљена. Значај противваздухопловне одбране и ракетних јединица за противваздухопловна дејства може се лако уочити на примеру Заливских ратова и у току оружаног сукоба између НАТО и Савезне Републике Југославије 1999. године.

Неопходно је истаћи и значај ракетних јединица опремљених ракетним системима за противваздухопловна дејства средњег домета у миру, у току реализације задатка контроле и заштите ваздушног простора и подршке управљању ваздушним саобраћајем. Значај овог задатка у спречавању повреде ваздушног простора и отклањању безбедоносне претње из ваздушног простора у миру се посебно повећао након 11.09.2011. године и терористичког напада у Сједињеним Америчким Државама (Петровић, Канкараш и Цветковић, 2015).

Република Србија је мала држава и у квалитативном и у квантитативном смислу

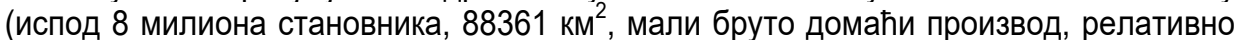
слаба економска развијеност, сложен геостратегијски и геополитички положај) што значајно утиче на њено опремање савременим борбеним системима, укључујући ракетни систем за противваздухопловна дејства средњег домета. На избор ракетног система посебан утицај има и полуприкупљен облик територије државе, као и тренутна расположивост системима за противваздухопловна дејства средњег домета ракетних јединица (Гордић и Петровић, 2014).

Имајући у виду наведено спроведено је истраживање чији је општи циљ: Вредновање критеријума за избор савременог ракетног система за противваздухопловна дејства средњег домета за потребе опремања ракетних јединица за противваздухопловна дејства у складу са могућностима државе применом фрази - АХП методе.

На основу циља изведена је општа хипотеза која гласи:

Применом фази - АХП методе могуће је извршити вредновање критеријума за избор савременог ракетног система за противваздухопловна дејства средњег домета за потребе опремања ракетних јединица за противваздухопловна дејства у складу са могућностима државе.

Примена фази - АХП методе омогућава реализацију процеса групног одлучивања узимањем у обзир неизвесности приликом оцене експерата што чини истраживање научно и методолошки оправданим. Ова процедура у својој суштини може бити примењена и у другима случајевима вредновања критеријума за избор различитих система оружја и војне опреме, као и приликом избора широког броја технолошких решења у другим сфрерама друштвеног живота, што ово истраживање чини и практично оправданим.

\section{Анализа литературе}

Постоји бројна литература која се бави вредновањем критеријума за избор система оружја. На пример, Mavris и DeLaurentis (1995) су истраживали концепт „свеукупних евалуацијских критеријума“ („overall evaluation criteria“) приликом селекције и вредновања критеријума за избор борбеног авиона. Вредновање критеријума за борбени авион применом АХП методе истраживао је Влачић (2013). Вишекритеријумска оптимизација карактеристика авиона истраживана је од стране Čokorilo et al (2010). На примеру избора противпожарне летелице, унапређење метода вишекритеријумског одлучивања приме- 
ном „интервалних фразних тешких бројева“ (interval-valued fuzzy-rough numbers) у свом раду објаснили су Памучар, Петровић и Ћировић (2018). Применом модификоване АХП методе помоћу фази бројева у истраживању проблема система одбране бавили су се Божанић, Памучар и Бојанић (2015) и Божанић, Памучар и Ћоровић (2013) у својим радовима. Значајан допринос у примени конвенционалних метода у фази окружењу приликом избора система оружја дали су у свом раду Dagdeviren, Yavuz и Kilinc (2009).

Начине и циљеве унапређења система противваздухопловне одбране, укључујући и унапређење ракетних јединица, у свом раду истраживали су Петровић, Канкараш и Цветковић (2015). Избор ракетног система за противваздухопловна дејства применом АХП методе истраживао је Жупац (2013). Одређивање и вредновање критеријума за избор ракетног система применом ДЕМАТЕЛ методе истраживали су Петровић и Канкараш (2017).

Међутим, вредновање критеријума за избор ракетног система за противваздухопловна дејства средњег домета у фрази окружењу није био до сада предмет ниједног научног рада.

\section{Критеријуми за избор ракетног система за противваздухопловна дејства}

На основу претходно извршене анализе садржаја постојеће научне литературе извршено је одређење критеријума и атрибута у оквиру сваког критеријума на основу којих је могуће извршити оптимални избор ракетног система за противваздухопловна дејства. Наведени критеријуми су прилагођени укупним евалуацијским критеријумима за избор борбеног система (Mavris \& DeLaurentis, 1995).

Критеријуми за избор ракетног система за противваздухопловна дејства средњег домета су следећи: приступачност (A), просторне перформансе (B), ватрене перформансе (C) и сигурност (D).

Атрибути критеријума приступачност су: трошкови опремања (A1), оперативни трошкови (A2), трошкови одржавања (A3), трошкови обуке (A4) и логистичка подршка (A5).

Атрибути критеријума просторне перформансе су: зона осматрања (B1), зона гађања (В2), зона уништења (В3) и величина резолуционе ћелије (B4).

Атрибути критеријума ватрене перформансе су: вероватноћа уништења циља (C1), степен каналности по циљу (C2), степен каналности по ракети (C3) и маневар ватром (C4).

Атрибути критеријума сигурност су: заштита снага (D1), маневар покретом (D2), пасивност сензора (D3), осетљивост на електронске сметње (D4) и десекти дизајна и одржавања (D5).

\section{Методологија}

За потребе вредновања критеријума и атрибута у оквиру критеријума за избор ракетног система применом методе фази - АХП (The Analytich Hierarchy Process) подаци су прикупљени помоћу технике скалирања, где је скала судова формирана на основу Сатијеве скале вредновања (Saaty, 1980). Применом стандардне Сатијеве 
скала, тада сваки елемент поређења матрице А може да има једну од 17 вредности из дискретног интервала $[1 / 9,9]$. Приоритизација, односно одређивање релативних тежина елемената на основу њихових вредности извршено је применом методе сопствених вредности - Eigenvector method - EV (Saaty, 1980). Пет експерата су извршили поређење критеријума и атрибута у оквиру сваког критеријума. Имајући у виду мали број експерата и распршеност добијених вредности извршено је фазирање крисп вредности (целобројна средња вредност добијених одговара експерата) помоћу троугластог фази броја (примењен један од приступа групног доношења одлука).

Процедура фазификације је спроведена на следећи начин:

Фази скуп А за сваки реалан број $a$, има вредност $\mu(a)$, где је $\mu(a)$ степен припадности $а$ троугластом фази броју $A^{\prime}$ и креће се у интервалу $[0,1]$. У општем смислу фази скуп се представља на следећи начин $\mathrm{A}=\{a, \mu(a)\}$.

Свакој крисп вредности $a_{i j}$ додељене су две вредности, помоћу којих је формиран фази број, који се може приказати у следећем векторском облику:

$a_{i j}^{\prime}=\left\{a_{i j}-\alpha, a_{i j,} a_{i j}+\alpha\right\}$, где је $1 / 2 \leq \alpha \leq 1$, у овом случају је једнако 1.

Наведене особине фази броја приказане су на слици број 1.

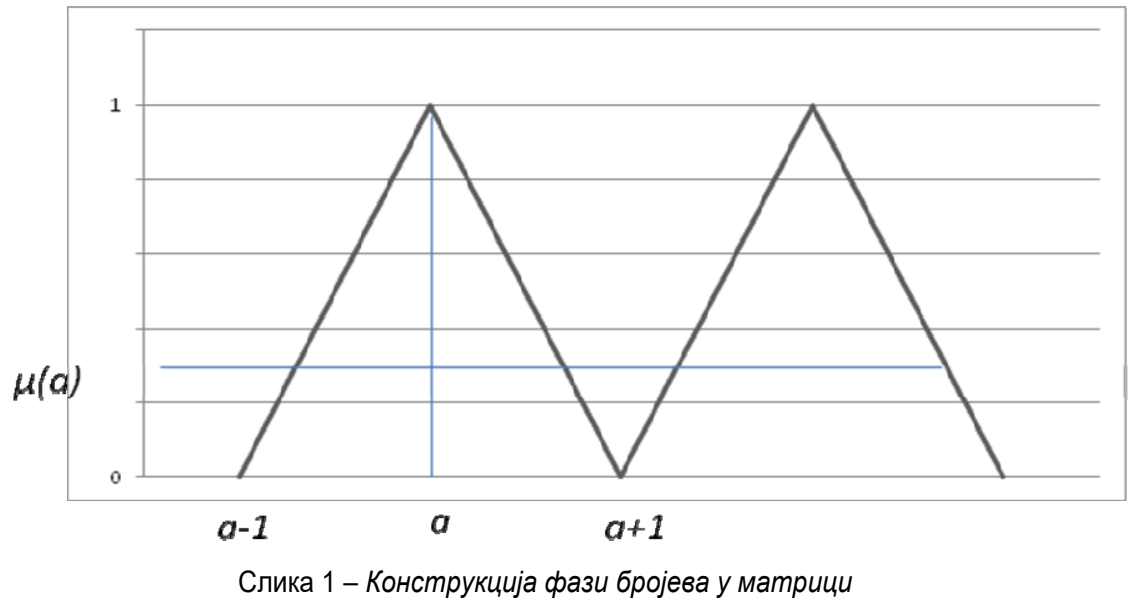

Имајући у виду да је прорачун вршен помоћу методе сопствених вредности, правила коришћења у раду са фрази бројевима су следећа:

$$
1 / a_{i j}=\left\{\frac{1}{a_{i j}+\alpha}, \frac{1}{a_{i j}}, \frac{1}{a_{i j}-\alpha}\right\},
$$




$$
\begin{aligned}
& a_{1}^{\prime} \oplus a_{2}^{\prime}=\left\{a_{11}^{\prime} \oplus a_{21}^{\prime}, a_{12}^{\prime} \oplus a_{22}^{\prime}, a_{13}^{\prime} \oplus a_{23}^{\prime}\right\}, \\
& a_{1}^{\prime} \div a_{2}^{\prime}=\left\{a_{11}^{\prime} \div a_{23}^{\prime}, a_{12}^{\prime} \div a_{22}^{\prime}, a_{13}^{\prime} \div a_{21}^{\prime}\right\},
\end{aligned}
$$

где је:

$$
\begin{aligned}
& a_{1}^{\prime}=\left\{a_{11}^{\prime}, a_{12}^{\prime}, a_{13}^{\prime}\right\} \\
& a_{2}^{\prime}=\left\{a_{21}^{\prime}, a_{22}^{\prime}, a_{23}^{\prime}\right\}
\end{aligned}
$$

Дефазификација фрази бројева у крисп вредност $w$ извршена је на следећи начин:

$$
w=\frac{\left(w_{11}^{\prime}, w_{12}^{\prime}, w_{13}^{\prime}\right)}{3}
$$

Конзистентност свих добијених резултата испитана је на почетној крисп вредности из матрице парне компарације на следећи начин (Памучар, 2017):

$$
C R=\frac{C I}{R I}
$$

$C I$ - индекс конзистентности

где је $C I=\frac{\lambda_{\text {max }}-n}{n-1}$

$\lambda_{\max }$ - максимална сопствена вредност матрице поређења (формула број 7):

$$
\lambda_{\max }=\frac{1}{n} \sum_{i=1}^{n} \lambda_{i}
$$

$$
\lambda_{i}=\frac{b_{i}}{w_{i}}
$$

Вредност $b_{i}$ је израчуната на следећи начин (формула број 9):

$$
\left[\begin{array}{l}
b_{1} \\
b_{2} \\
b_{n}
\end{array}\right]=\left[\begin{array}{lll}
a_{11} & a_{12} & a_{1 n} \\
a_{21} & a_{22} & a_{2 n} \\
a_{n 1} & a_{n 2} & a_{n n}
\end{array}\right]\left[\begin{array}{l}
w_{1} \\
w_{2} \\
w_{n}
\end{array}\right]
$$

$R I$ - случајни индекс, који зависи од броја редова - колона матрице n (Памучар, 2017). Уколико је $C R \leq 0.10$ онда резултат задовољава потребе истраживања. 


\section{Прорачун вредновања критеријума за избор ракетног система за противваздухопловна дејства}

На основу описане процедуре формирана је почетна матрица преференције за критеријуме: приступачност (A), просторне перформансе (B), ватрене перформансе (C) и сигурност (D).

Табела 1 - Матрица префреренције за критеријуме

\begin{tabular}{|c|c|c|c|c|}
\hline K & A & B & C & D \\
\hline A & $(1,1,1)$ & $(2,3,4)$ & $(2,3,4)$ & $(4,5,6)$ \\
\hline B & $(0.25,0.33,0.5)$ & $(1,1,1)$ & $(2,3,4)$ & $(4,5,6)$ \\
\hline C & $(0.25,0.33,0.5)$ & $(0.25,0.33,0.5)$ & $(1,1,1)$ & $(1,1,1)$ \\
\hline D & $(0.17,0.2,0.25)$ & $(0.17,0.2,0.25)$ & $(0.25,0.33,0.5)$ & $(1,1,1)$ \\
\hline
\end{tabular}

На основу вредности из матрице преференције према формули број 4 израчуната је матрица нормализованих вредности (Saaty, 1980):

$$
a_{i j}^{\prime \prime}=\frac{a_{i j}^{\prime}}{\sum_{j=1}^{n} a_{i j}^{\prime}}
$$

Где је:

$$
\begin{aligned}
& a_{i j}^{\prime \prime}=\left\{a_{i j 1}^{\prime \prime}, a_{i j 2}^{\prime \prime}, a_{i j 3}^{\prime \prime}\right\}, \\
& a_{i j 1}^{\prime \prime}=\frac{a_{i j 1}^{\prime}}{\sum_{j=1}^{n} a_{i j 3}^{\prime}}, a_{i j 2}^{\prime \prime}=\frac{a_{i j 2}^{\prime}}{\sum_{j=1}^{n} a_{i j 2}^{\prime}}, a_{i j 3}^{\prime \prime}=\frac{a_{i j 3}^{\prime}}{\sum_{j=1}^{n} a_{i j 1}^{\prime}}
\end{aligned}
$$

Табела 2 - Матрица нормализованих вредности за критеријуме

\begin{tabular}{|c|c|c|c|c|}
\hline K & A & B & C & D \\
\hline A & $(0.44,0.54,0.6)$ & $(0.35,0.66,1.17)$ & $(0.21,0.41,0.76)$ & $(0.24,0.36,0.55)$ \\
\hline B & $(0.11,0.18,0.3)$ & $(0.17,0.22,0.29)$ & $(0.21,0.41,0.76)$ & $(0.24,0.36,0.55)$ \\
\hline C & $(0.11,0.18,0.3)$ & $(0.04,0.07,0.15)$ & $(0.11,0.14,0.19)$ & $(0.12,0.21,0.36)$ \\
\hline D & $(0.07,0.11,0.15)$ & $(0.03,0.04,0.07)$ & $(0.03,0.05,0.1)$ & $(0.06,0.07,0.09)$ \\
\hline
\end{tabular}


Помоћу формула 2, 4 и 12 из матрице нормализованих вредности добијене су вредности релативних тежинских коефицијената W, који су приказани у табели 3.

$$
w_{i}=\sum_{j=1}^{n} a_{i j}^{\prime \prime} /
$$

Табела 3 - Тежински коефицијенти за критеријуме (метода сопствених вредности)

\begin{tabular}{|c|c|c|c|c|c|c|}
\hline K & A & B & C & D & $w_{i}$ & Ранг \\
\hline A & $(0.44,0.54,0.6)$ & $(0.35,0.66,1.17)$ & $(0.21,0.41,0.76)$ & $(0.24,0.36,0.55)$ & 0.49 & 1 \\
\hline B & $(0.11,0.18,0.3)$ & $(0.17,0.22,0.29)$ & $(0.21,0.41,0.76)$ & $(0.24,0.36,0.55)$ & 0.29 & 2 \\
\hline C & $(0.11,0.18,0.3)$ & $(0.04,0.07,0.15)$ & $(0.11,0.14,0.19)$ & $(0.12,0.21,0.36)$ & 0.15 & 3 \\
\hline D & $(0.07,0.11,0.15)$ & $(0.03,0.04,0.07)$ & $(0.03,0.05,0.1)$ & $(0.06,0.07,0.09)$ & 0.07 & 4 \\
\hline
\end{tabular}

Приоритетизацију критеријума могуће је извршити, уједно и проверити, применом геометријских средњих вредности прорачунатих на фрази бројевима. Вредности релативних тежинских коефицијената $w_{i}$ у фази броју су добијени на следећи начин (Gungor, Serdagioglu and Kesen, 2009):

$$
w_{i}=\frac{\prod_{j=1}^{n} a_{i j}^{\prime}}{\sum_{i=1}^{n} \prod_{j=1}^{n} a_{i j}^{\prime}}
$$

Вредности $w_{i}$ су добијени применом правила број 2 и 3 на формули број 13, а крисп вредност је одређена помоћу формуле број 4, након чега је извршена коначна нормализације релативних тежина (табела број 4).

Табела 4 - Тежински коефрицијенти за критеријуме (метода геометријских средњих вредности матрица)

\begin{tabular}{|c|c|c|c|c|c|c|}
\hline $\mathrm{K}$ & $\mathrm{A}$ & $\mathrm{B}$ & $\mathrm{C}$ & $\mathrm{D}$ & $w_{i}$ & $w_{i}$ \\
\hline $\mathrm{A}$ & $(1,1,1)$ & $(2,3,4)$ & $(2,3,4)$ & $(4,5,6)$ & $(0.31,0.5,0.77)$ & 0.49 \\
\hline $\mathrm{B}$ & $(0, .25,0.33,0.5)$ & $(1,1,1)$ & $(2,3,4)$ & $(4,5,6)$ & $(0.19,0.29,0.46)$ & 0.29 \\
\hline $\mathrm{C}$ & $(0.25,0.330 .5)$ & $(0.25,0.33,0.5)$ & $(1,1,1)$ & $(1,1,1)$ & $(0.09,0.15,0.25)$ & 0.15 \\
\hline $\mathrm{D}$ & $(0.17,0.2,0.25)$ & $(0.17,0.2,0.25)$ & $(0.25,0.33,0.5)$ & $(1,1,1)$ & $(0.05,0.07,0.1)$ & 0.07 \\
\hline
\end{tabular}


Табела 5 - Сопствене вредности матрице поређења

\begin{tabular}{|c|c|c|c|c|c|c|}
\hline $\mathrm{K}$ & $\mathrm{A}$ & $\mathrm{B}$ & $\mathrm{C}$ & $\mathrm{D}$ & $b_{i}$ & $\lambda_{i}=\frac{b_{i}}{w_{i}}$ \\
\hline $\mathrm{A}$ & 0.49 & 0.87 & 0.45 & 0.35 & 2.16 & 4.41 \\
\hline $\mathrm{B}$ & 0.16 & 0.29 & 0.45 & 0.35 & 1.25 & 4.32 \\
\hline $\mathrm{C}$ & 0.16 & 0.10 & 0.15 & 0.21 & 0.62 & 4.13 \\
\hline $\mathrm{D}$ & 0.10 & 0.06 & 0.05 & 0.07 & 0.28 & 3.94 \\
\hline
\end{tabular}

На основу формуле 7 добијамо да је $\lambda_{\max }=4.2$, а $C I=0.07$. За $n=4 \Rightarrow R I=0.89$ (Saaty, 1980). На основу формуле број 5, добијена је вредност $C R=0.07$, што је мање 0.1 . На основу наведеног закључено је да су резултати конзистентни.

Применом истих процедура израчунате су вредности релативних тежина атрибута, који су приказани у табели број 6, где је приказан предложен модел критеријума и атрибута са релативним тежинским вредностима.

Табела 6 - Модел вредновања критеријума и атрибута приликом избора понуђених алтернатива опремања ракетних јединица савременим системом за противваздухопловна дејства средњег домета

\begin{tabular}{|c|c|c|c|c|c|c|}
\hline \multicolumn{6}{|c|}{ Релативне тежине атрибута критеријума } & $w_{i}$ \\
\hline A & A1 & A2 & A3 & A4 & A5 & \multirow{2}{*}{0.49} \\
\hline $\mathrm{a} w_{i}$ & 0.25 & 0.08 & 0.05 & 0.04 & 0.07 & \\
\hline B & B1 & B2 & B3 & B4 & & \multirow{2}{*}{0.29} \\
\hline $\mathrm{b} w_{i}$ & 0.09 & 0.03 & 0.11 & 0.06 & & \\
\hline C & $\mathrm{C} 1$ & $\mathrm{C} 2$ & C3 & C4 & & \multirow{2}{*}{0.15} \\
\hline $\mathrm{c} w_{i}$ & 0.04 & 0.09 & 0.01 & 0.01 & & \\
\hline D & D1 & D2 & D3 & D4 & D5 & \multirow{2}{*}{0.07} \\
\hline $\mathrm{d} w_{i}$ & 0.02 & 0.01 & 0.03 & 0.005 & 0.005 & \\
\hline
\end{tabular}

Степени конзистентности приликом приоритетизације атрибута свих критеријума имају вредност мању од 0.1 (иако су дозвољена одговарајућа одступања као последица степена неизвесности фази бројева), што за последицу има поузданост и конзистентност резултата истраживања (постоји континуирана конзистентност у одговорима експерата). 


\section{Дискусија}

Приоритетизација критеријума и атрибута критеријума за избор ракетног система за противваздухопловна дејства је била предмет истраживања неколико научних радова до сада. У свом истраживању Жупац (2013) године је применом АХП методе извршио вредновање критеријума и атрибута (укупно 43 критеријума на три нивоа). Према његовим резултатима најзначајнији критеријум су борбене могућности ракетног система са релативном тежином од 0.374 , док је најмање значајан критеријум компатибилност ракетног система са тренутно постојећим ракетним системима у Војсци (вредност релативне тежине износи 0.026). У свом раду Петровић и Канкараш (2017) су применом ДЕМАТЕЛ методе истраживали релативне тежине критеријума за избор ракетног система за противваздухопловна дејства. У овом истраживању приоритетизација је вршена за четири критеријума (економичност, ефективност, одржавање и борбене могућности ракетног система за противваздухопловна дејства). У овом случају најзначајнији критеријум су борбене могућности, док је најмање значајан критеријум одржавање ракетног система.

За разлику од наведених, у овом раду је приоритетизација извршена применом фази - АХП, која представља један од алата групног доношења одлука, где је број испитаника мали (мањи од 10, у овом случају пет), и где је узета у обзир неизвесност прикупљених података што није био случај у ранијим радовима (експоненцијалну зависност поузданости резултата од броја експерата истраживао је Марцынковский (2011). Наиме, у овом раду је извршен одабир експерата од специјалиста, чиме је из процеса одлучивања делимично избачена сугестибилност (утицај јачих фактора на слабије). Такође, неопходно је истаћи да се рад односи на потребу приоритетизације критеријума за потребе избора ракетног система са становишта употребе у миру (безбедност ваздушног саобраћаја) и оружаном сукобу. Критеријуми за избор ракетног система за противваздухопловна дејства су следећи: приступачност са релативном тежином од 0.49, затим просторне перформансе са релативном тежином 0.29, затим ватрене перформансе са 0.17 и сигурност са релативном тежином од 0.07. На основу резултата истраживања може се закључити следеће: експерти ипак сматрају да је економски аспект, а нарочито услови набавке, има велики утицај на избор и финансијску одрживост опремања и експлоатације ракетног система (имајући у виду релативно мали бруто домаћи производ државе). Такође, интересантно је да је дат већи значај просторним, од ватрених перформанси, док је значај сигурности, уједно и заштите снага веома мали. Очигледно је да експерти сматрају да је потребно тенденцију набавки ракетних система за противваздухопловна дејства усмерити на веће домете, чиме би се смањио број ватрених јединица, као и да је неопходно значајно повећати могућност једновременог гађања више летелица у ваздушном простору у случају масовних удара ваздухопловних снага. Могуће образложење за мали значај заштите снага и заштите од електронских дејстава непријатеља јесте да су експерти уверени да је ракетни систем неопходнији за мир и секундарну заштиту ваздушног простора и заштиту управљања ваздушним саобраћајем, него за рат. Друго образложење би било да су мишљења да сви савремени ракетни системи располажу већ адекватним електронским системима и средствима за одбрану од електронског напада непријатеља. 
На основу наведеног резултата истраживања може се закучити да је циљ истраживања у потпуност испуњен и да је постављена хипотеза позитивно верификована. Предложени модел се може унапредити применом квалитативно потпунијих метода вишекритеријумског одлучивања са узимањем у обзир степена уверености експерата, а сам модел се може применити за избор ракетног система за противваздухопловна дејства применом одговарајућих метода операционих истраживања (на пример: ТОПСИС, ВИКОР и слично).

\section{Закључак}

Избор оптималне алтернативе приликом опремања система одбране новим ракетним системом за противваздухопловна дејства средњег домета представља један од најбитнијих задатака у наредном периоду Ратног ваздухопловства и противваздухопловне одбране. Ово је последица утицаја који имају дејства која изводе ваздухопловне и противваздухопловне снаге у савременим оружаним сукобима, као и значаја система противваздухопловне одбране у реализацији задатка контроле и заштите ваздушног простора у миру. Задатак контроле и заштите ваздушног простора представља незаменљив сегмент управљања ваздушним саобраћајем, што проблем опремања савременим вишенаменским борбеним авионима, ракетним системима за противваздухопловна дејства, радарско - рачунарским средствима и компонентама командно - информационог система ставља све више у фокус не само одбрамбених, него и државних питања.

У наредним истраживањима неопходно је даље се усресредити на унапређење модела за избор не само ракетног система, већ и других система оружја и опреме (посебно оних софистицираних) уз спровођење техно-економске анализе. Избор система оружја и опреме у Ратном ваздухопловству и притвваздухопловној одбрани је сложен и дуготрајан процес, који дугорочно трасира организациону и функционалну структуру ваздухопловних и противваздухопловних снага. Због тога је неопходно овом питању посветити интердисциплинаран приступ уз уважавање, како стручне, тако и академске јавности. Примена метода вишекритеријумског одлучивања, која узимају у обзир неизвесност је само један од корака у решавању тог и сличних проблема.

\section{Лumepamypa}

[1] Božanić, D., Pamučar, D. \& Bojanić, D. (2015). Modification of the analytic hierarchy process (ahp) method using fuzzy logic: fuzzy ahp approach as a support to the decision making process concerning engagement of the group for additional hindering. Serbian Journal of Management 10 (2), 151 - 171.

[2] Čokorilo, O., Gvozdenović, S., Mirosavljević, P. \& Vasov, L. (2010). Multi Attribute Decision Making: Assessing the Technological and Operational Parameters of an Aircraft.Transport, Vol. 25, No. 4, 352-356.doi.org/10.3846/transport.2010.

[3] Dagdeviren, M., Yavuz, S. \& Kilinc, N. (2009). Weapon selection using the AHP and TOPSIS methods under fuzzy environment. Expert Systems with Applications, Vol. 2009, No. 36, 8143-8151. preuzeto sa: www.elsevier.com/locate/eswa 
[4] Dagdeviren, M., Yavuz, S., \& Kilinc, N. (2009). Weapon selection using the AHP and TOPSIS methods under fuzzy environment. Expert Systems with Applications, 2009 (36), 8143-8151. doi.elsevier.com/locate/eswa

[5] Gungor, Z., Serdagioglu, G. \& Kesen, S.E. (2009). A fuzzy AHP approach to personnel selection problem. Applied Soft Computing, Vol. 2009, No. 9, 641-646.

[6] Mavris, D. \& DeLaurentis, D. (1995). An Integrated Approach to Military Aircraft Selection and Concept Evaluation. The 1st AIAA Aircraft Engineering, Technology, and Operations Congress, Los Angeles (1-11). American Institute of Aeronautics and Astronautics

[7] Pamucar, D., Petrovic, I. \& Cirovic, G. (2018). Modification of the Best-Worst and MABAC methods: A novel approach based on interval-valued fuzzy-rough numbers, Expert Systems with Applications, 91, 89-106.

[8] Petrović, I. \& Kankaraš. M. (2017). Determination and Evaluation Criteria for Equipping the Small Country with Anti-aircraft Missile System. ICMNEE 2017. Beograd.

[9] Petrović, I., Kankaraš, M. \& Cvetković, K. (2015). Significance and Prospects of the Development of Defence System. Vojno delo, Vol. 67, No. 6, 86-98. doi: 10.5937/vojdelo1506086P

[10] Saaty, T.L. (1980). The analytic hierarchy process. New York. McGraw-Hill.

[11] Божанић, Д., Памучар, Д. \& Ћоровић Б. (2013). Модификација методе аналитичког хијерархијског процеса и њена примена у доношењу одлука у систему одбране. Техника менаџмент 63 (2), 327-334.

[12] Влачић, С. (2012). Дефинисање критеријума за избор вишенаменског борбеног авиона за потребе Ваздухопловства и противваздухопловне одбране Војске Србије. Београд: Универзитет одбране.

[13] Гордић, М. \& Петровић, И. (2014). Ракетни системи у одбрани малих држава. Београд: МЦ Одбрана.

[14] Жупац, Г. (2013). Модел одређивања и евалуације критеријума за избор ракетног система противваздухопловне одбране средњег домета. Београд. Универзитет одбране

[15] Марцынковский, Д. (2011). Использование метода экспертных оценок при анализе и оценке рисков системы менеджмента, Часть 4, Itech - интеллектуальные технологии: журнал интеллектуальных технологий, Томск, 18. 